\title{
Soil biological properties and fungal diversity under conservation agriculture in Indo-Gangetic Plains of India
}

\author{
Madhu Choudhary ${ }^{1 *}$, Parbodh Chander Sharma ${ }^{1}$, Hanuman Sahay Jat ${ }^{2}$, Andrew \\ McDonald $^{3}$, Mangi Lal Jat ${ }^{2}$, Sharda Choudhary ${ }^{4}$, Neelam Garg ${ }^{5}$
}

${ }^{1}$ ICAR-Central Soil Salinity Research Institute (ICAR-CSSRI), Karnal, India. ${ }^{2}$ International Maize \& Wheat Improvement Centre (CIMMYT), India. ${ }^{3}$ International Maize \& Wheat Improvement Centre (CIMMYT), Nepal

${ }^{4}$ National Research Centre on Seed Spices, Ajmer, India. ${ }^{5}$ Kurukshetra University, Kurukshetra, India

*Corresponding author: madhu.choudhary@icar.gov.in

\begin{abstract}
A field experiment was undertaken to evaluate the effect of conservation agriculture (CA) based management on soil biological properties, and on fungal diversity and abundance after 5 years of continuous cultivation. Treatments included four crop managements viz., conventional tillage (CT) rice-wheat (CT-RW; CT based), conventional tillage rice-zero tillage wheat and mungbean (CTR-ZTWMb; partially CA based), zero tillage rice-wheat-mungbean (ZT-RWMb; full CA based), and zero tillage maize-wheatmungbean (ZT-MWMb; full CA based). Full rice, maize, and mungbean crop residue and anchored wheat residue were recycled in CA-based managements, while CT-based management was without any residue. Full CA-based management (ZT-MWMb) recorded 43\% higher organic carbon, 56\% microbial biomass carbon, 70\% microbial biomass nitrogen, 73\% phosphatase activity, and 40\% $\beta$-glucosidase activity, than CT-RW management. Ascomycota (55-74\%) was the dominant phylum followed by Basidiomycota and Glomeromycota (0 to 3\%); abundance of these phyla varied amongst managements. Ascomycota abundance was in order of CT-RW $<\mathrm{CTR}-\mathrm{ZTWMb}<\mathrm{ZT}-\mathrm{RWMb}<\mathrm{ZT}-\mathrm{MWMb}$, however, Basidiomycota and Glomeromycota did not follow any trend. Diversity indices such as species richness, evenness and Shannon-Wiener diversity index were in the order: ZT-MWMb $>$ ZT-RWMb $>$ CTR-ZTWMb $>$ CT-RW. This study clearly showed that CA with all three proven principles (no-tillage, residue retention and crop diversification) in maize-wheat-mungbean system resulted in higher microbial activities, fungal diversity and species richness compared to other cereal based management systems.
\end{abstract}

Keywords: Conservation agriculture, soil biological activities, fungal diversity and abundance, cereal based cropping systems. 


\section{Introduction}

The rice-wheat (RW) cropping system is one of the world's largest agricultural production systems, covering an area of 26 million hectares spread over the Indo-Gangetic Plains (IGP) in South Asia and China (Sarkar, 2015). In South Asia, more than $85 \%$ of the RW system is practiced in the IGP. The sustainability of this important cropping system is at risk due to second-generation problems related to degradation of natural resources (soil health, air quality, and ground water depletion), and mono cropping (inadequate system diversity) under conventional tillage (farmer's practice/ 'business as usual') based management systems (Gathala et al., 2013). Furthermore, this risk is intensified with in-situ burning of crop residues which hampered the soil biological activities and microbial diversity (Lohan et al., 2017). To overcome formidable problems of the RW system in South Asia, conservation agriculture (CA) has emerged as an important alternative to conventional RW system. Higher yields of rice/maize were recorded with CA-based management practices over conventional management due to the improved soil quality indices (Choudhary et al., 2018). The activity and diversity of soil microbial populations are directly affected by management practices (as tillage, crop establishment, residue disposal, water and nutrient management), and soil environment. Microbial biomasses which are sensitive indicators of changes in soil organic matter, are influenced by agriculture management practices (Madejón et al., 2009). Microbial enzymes are involved in soil nutrient cycling, and are used to evaluate soil quality (Choudhary et al., 2018).

Among soil microbes, fungi are critical components in soil system and are regarded as the primary decomposers in soils, as they secrete various enzymes that breakdown lignocelluloses (Choudhary et al., 2016). Plenity of data reported on fungal communities in dif- ferent natural soil habitats (Marín et al., 2017), but less is so far known about fungal communities in agricultural soils, and very limited in conservation agriculture practices (Wang et al., 2016). An in-depth understanding of the fungal community in agricultural soils provides the path to study their roles in agro-ecosystems, which is not possible by traditional methods like culture-based methods and microscopic studies. With the advanced techniques of metagenomic analysis it is possible to decipher taxonomic and functional assemblages of natural indigenous communities, and their roles in the ecosystems. To date, this approach has been less used to evaluate the impact of agricultural practices on soil microbial communities (Wang et al., 2016). Different agricultural practices like tillage, residue management, crop rotation, etc., affect the physical and chemical characteristics of the soil where microorganism live, thereby affecting their abundance, diversity, and activity (Govaerts et al., 2007). In the North-West IGP of India most of farmers follow the rice-wheat cropping system with conventional-till (intensive tillage) management practices. In this situation the microbial activity is influenced largely by tillage practices as reported for the IGP (Choudhary et al., 2018). In CA based management, retention of crop residue ( $>12 \mathrm{t} / \mathrm{ha}$ every year) provides carbon and nutrients, and micro-climatic conditions for microbes therefore an increase in the microbial activity fungal diversity is expected. We hypothesize that fungal abundance would increase in CA based management practices compared to intensive tillage based system and pattern of abundance of different fungal class, orders, and genus will also influenced by management practices. Very scarce information is available on fungal diversity and species richness in CA managed systems (rice and maize) of IGP. In this study, efforts have been made to evaluate 
the effects of CA based management practices (tillage, crop establishment, residue management, and cropping system intensification) on soil microbial activities, fungal diversity and fungal community structure in comparison to conventional-till RW systems of IGP.

\section{Materials and Methods}

\subsection{Study site and experimental design}

To study the impact of different agricultural practices on soil biological properties and microbial diversity, a field experiment with different management prac- tices, including crop rotation, tillage and residue management was started in 2009 by the International Maize and Wheat Improvement Center (CIMMYT) at the Indian Council of Agricultural Research (ICAR) -Central Soil Salinity Research Institute (29.7057oN latitude, $76.9554 \mathrm{oE}$ longitude and at an elevation of 243 m.a.s.1.), Karnal, India (Figure 1). Climate of the region is semi-arid and sub-tropical with extreme weather conditions with hot and dry (April- June) to wet summers (July-September) and cold dry winters (October- March) with an average annual rainfall of $670 \mathrm{~mm}, 75-80 \%$ of which is received during the monsoon season. The soil characteristics of the experimental site are given in Table 1.

Table 1. Initial soil characteristics ( $0-15 \mathrm{~cm}$ layer) of experimental site

\begin{tabular}{ll}
\hline Soil property & Value \\
\hline Clay (\%) & $19.9 \pm 0.50$ \\
Silt (\%) & $46.1 \pm 0.76$ \\
Sand (\%) & $34.0 \pm 0.77$ \\
Textural class & Loam \\
pH (1:2 soil:water) & $8.00 \pm 0.02$ \\
Electric conductivity (dS m $\left.{ }^{-1}\right)(1: 2$ soil:water) & $0.37 \pm 0.02$ \\
Total organic carbon $(\%)$ & $0.56 \pm 0.01$ \\
Total N (\%) & $0.06 \pm 0.002$ \\
Olsen P (available P) $\left(\mathrm{kg} \mathrm{ha}^{-1}\right)$ & $12.6 \pm 0.29$ \\
$1 N \mathrm{NH}_{4} \mathrm{OAc}-$ extreactable K (available K) $\left(\mathrm{kg} \mathrm{ha}^{-1}\right)$ & $130 \pm 1.73$ \\
\hline
\end{tabular}

For all variables $n=3 \pm$ standard error of mean. 


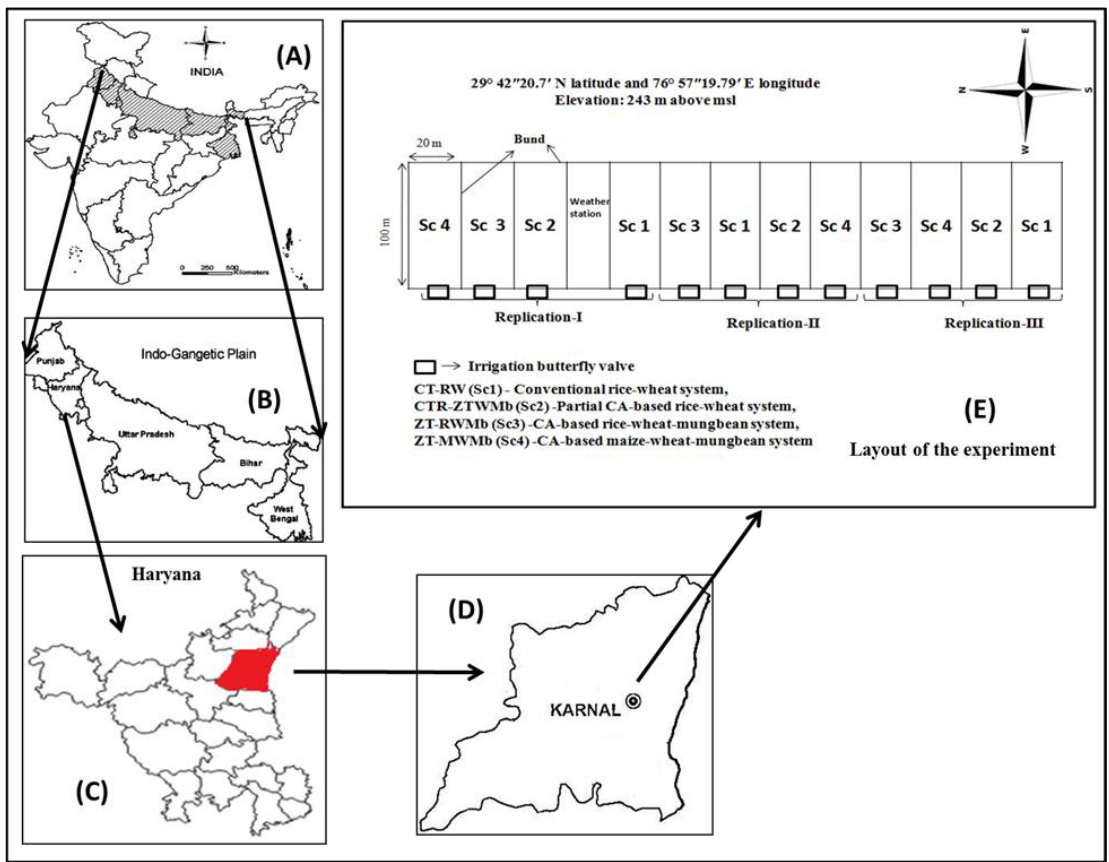

Figure 1. Maps of (A) India, (B) Indo Gangetic Plains (IGP), (C) Haryana (D) Karnal (E) experimental site and lay out of treatments

The managements scenarios were designed keeping in view present as well as future drivers of agricultural changes in the region (Table 2). Treatments included four cereal-based cropping managements varying in cropping system, tillage, crop establishment methods, and crop residue management practices. Managements were organized in a randomized complete block design and replicated three times in productionscale plots, each one measuring $2000 \mathrm{~m}^{2}(20 \mathrm{~m}$ x 100 $\mathrm{m})$. The four managements viz., Rice \{conventional tillage (CT)/transplanted rice (TPR) $\}$-wheat (CT) rotation which is conventional-till based current farmers' practice in NW-IGP of India (CT-RW); ricewheat-mungbean $\{\mathrm{CT} / \mathrm{TPR}-\mathrm{ZT}$ (zero-tillage)-ZT $\}$ with $100 \%$ residue retention/ incorporation (CTRZTWMb); rice-wheat-mungbean (ZT-ZT-ZT) with $100 \%$ residue retention (ZT-RWMb); maize-wheatmungbean (ZT-ZT-ZT) with $65 \%$ of maize and $100 \%$ of wheat-mungbean residue retention (ZT-MWMb). Management 2 (CTR-ZTWMb) is partially CA whereas management 3 and 4 (ZT-RWMb and ZT$\mathrm{MWMb}$ ) are full CA based practices (Table 2) and other details of these managements can be obtained from a previous study (Gathala et al., 2013). 
Table 2. Different scenarios of conservation agriculture management practices

\begin{tabular}{lll}
\hline Scenarios & $\begin{array}{l}\text { Cropping } \\
\text { system }\end{array}$ & Management system \\
\hline CT-RW & $\begin{array}{l}\text { Rice- } \\
\text { Wheat }\end{array}$ & $\begin{array}{l}\text { Rice-puddling, Wheat-conventional till; All residue } \\
\text { removed (current farmers' practice) }\end{array}$ \\
$\begin{array}{l}\text { CTR- } \\
\text { ZTWMb }\end{array}$ & $\begin{array}{l}\text { Rice- } \\
\text { Wheat- }\end{array}$ & $\begin{array}{l}\text { Rice- puddling, Wheat- zero-till, Mungbean- zero-till; Full } \\
(100 \%) \text { rice residue retained; partial (30\%) wheat residue } \\
\text { (anchored); and full (100\%) mungbean residues }\end{array}$ \\
incorporated during puddling in rice season \\
ZT-RWMb & $\begin{array}{l}\text { Rice- } \\
\text { Wheat- } \\
\text { Mungbean }\end{array}$ & $\begin{array}{l}\text { Rice- zero-till, Wheat- zero-till, Mungbean- zero-till; Full } \\
\text { rice and mungbean whereas partial (anchored) wheat } \\
\text { residue retained on soil surface }\end{array}$ \\
ZT-MWMb & $\begin{array}{l}\text { Maize- } \\
\text { Wheat- } \\
\text { Mungbean }\end{array}$ & $\begin{array}{l}\text { Maize- zero-till, Wheat- zero-till, Mungbean- zero-till; } \\
\text { Full maize and mungbean whereas partial (anchored) } \\
\text { wheat residue retained on soil surface }\end{array}$
\end{tabular}

$C T-R W$ conventional tillage rice-wheat, $C T R-Z T W M b$ conventional tillage rice- zero tillage wheat and mungbean, $Z T-R W M b$ zero tillage rice-wheat-mungbean, $Z T-M W M b$ zero tillage maize-wheat-mungbean

\subsection{Soil sampling and processing}

Soil samples were collected after the harvesting of the wheat crop during April-May 2014, from 0-15cm soil depth using an auger $(5 \mathrm{~cm}$ internal diameter). Each plot was divided into four $50 \mathrm{~m} \times 10 \mathrm{~m}$ grids. Within each plot, sub-samples were collected from nine locations and then a composite sample of each plot was prepared. The samples were wet sieved (2-mm mesh) and a subsample was stored at $-20^{\circ} \mathrm{C}$ for DNA extraction. The remaining portion of the fresh soil samples was kept in a refrigerator at $4{ }^{\circ} \mathrm{C}$ for analysis of soil biological parameters. DNA extraction was done on the next day of sampling; other parameters were also analyzed within one month. Samples were pre-incubated at room temperature overnight before analyzing the microbial biomass carbon (MBC), microbial biomass nitrogen (MBN), and soil enzymes activities. All equipments like the augur and the sieve were wiped thoroughly with alcohol before every use.

\subsection{Analysis of soil samples}

Electrical conductivity (EC) and $\mathrm{pH}$ of soil samples in soil: water (1:2) dilution was determined by following standard methods (Jackson, 1973). Dehydrogenase activity (DHA) was tested from the conversion of 2,3,5- triphenyl tetrazolium chloride (TTC) to triphenyl formazan (TPF) over a 24-h period. Soil (20 g) was mixed with $0.2 \mathrm{~g} \mathrm{CaCO}_{3}$, and from this $6 \mathrm{~g}$ were placed in each of three test tubes. Aqueous solution of 3\% TTC and $2.5 \mathrm{ml}$ distilled water was added and incubated at $37^{\circ} \mathrm{C}$. After $24 \mathrm{~h}, 10 \mathrm{ml}$ methanol was added. Intensity of reddish color filtrate (TPF) was measured by UV/VIS spectrophotometer (LABINDIA UV 3000+) at 485nm wavelength (Dick, 1997). Alkaline phosphatase activity (APA) was analysed as described by Eivazi and Tabatabai (1977); briefly APA was determined by measuring the release of $\mathrm{p}$ nitrophenol by incubating $1 \mathrm{~g}$ soil at $37^{\circ} \mathrm{C}$ for $1 \mathrm{~h}$ with $0.2 \mathrm{ml}$ toluene, $4 \mathrm{ml}$ universal buffer $(\mathrm{pH} 11.0)$, and 
$1 \mathrm{ml} 50 \mathrm{mmol}$ p-nitrophenyl phosphate. Yellow color intensity of p-nitrophenol was measured at $400 \mathrm{~nm}$ wavelength. Activity of $\beta$-glucosidase was analysed by the method of Alef and Nannipieri (1995). Microbial biomass carbon (MBC) and nitrogen (MBN) were estimated by chloroform fumigation method (Vance et al., 1987). The values of $\mathrm{KC}$ and $\mathrm{KN}$ were taken 0.38 and 0.45 , respectively for MBC and MBN.

\subsection{DNA extraction and sequencing}

The metagenomic DNA was extracted from $0.25 \mathrm{~g}$ soil, using PowerSoil ${ }^{\circledR}$ DNA isolation kit (MO BIO Laboratories Inc., Carlsbad, California, USA) following the manufacturer's protocol. The DNA was quantified, and its purity was checked using Nano Drop spectrophotometer (Thermo Fisher Scientific, USA) at the wavelengths of $260 \mathrm{~nm}$ and $280 \mathrm{~nm}$. The DNA purity and quantity were also verified by electrophoresis in $1 \%$ agarose gel and samples were adjusted to $50 \mathrm{ng} / \mu \mathrm{L}$. The DNA was amplified for the fungal ITS region using universal forward ITS1-F primer CTTGGTCATTTAGAGGAAGTAA and the reverse ITS1Univ-R primer GCTGCGTTCTTCATCGATGC. The amplifications were performed in $25 \mu \mathrm{l}$ reactions with Qiagen HotStar Taq master mix (QiagenInc, New Delhi), $1 \mu$ of each $5 \mu \mathrm{M}$ primer, and $1 \mu 1$ of template. The reactions were performed on ABI Veritithermocyclers (Applied Biosytems, UK) under the following thermal profile: $95{ }^{\circ} \mathrm{C}$ for $5 \mathrm{~min}$, then 35 cycles of $94{ }^{\circ} \mathrm{C}$ for $30 \mathrm{sec}, 54{ }^{\circ} \mathrm{C}$ for $40 \mathrm{sec}, 72{ }^{\circ} \mathrm{C}$ for $1 \mathrm{~min}$, followed by one cycle of $72{ }^{\circ} \mathrm{C}$ for $10 \mathrm{~min}$, and $4{ }^{\circ} \mathrm{C}$ hold. The amplification products were visualized with eGels (Life Technologies, Grand Island, New York, USA). The products were then equimolarly pooled and each pool was size-selected in two rounds using Agencourt AMPure XP (BeckmanCoulter, Indianapolis, Indiana, USA) in a 0.7 ratio for both rounds. The size selected pools were then quantified using the Quibit 2.0 fluorometer (Life Technologies, Grand Island, New York, USA) and loaded on an Illumina MiSeq (Illumina, Inc. San Diego, California, USA) $2 \times 300$ flow cell at 10pM.

\subsection{Bioinformatic and statistical analyses}

The data analysis was carried out in two stages denoising and chimera detection, followed by microbial diversity analysis. The paired-end reads were demultiplexed by Illumina supplied CASAVA . The primer binding sequences were filtered and its quality was checked using FastQC v 0.11.4 (Andrews et al., 2010). The low quality reads trimming and paired end reads merging was performed using PEAR v 2.1 (Zhang et $a l ., 2013$ ) The reads with base quality less than 25 were trimmed in order to retain high quality reads. Dereplication is performed using USEARCH 7 (Edgar, 2010) prefix-based algorithm that groups reads into clusters that shows $100 \%$ match to the centroid sequence. The sequences with a length greater than $100 \mathrm{bp}$ were retained. Clustering at $4 \%$ divergence (consensus sequences) is performed using the USEARCH clustering algorithm where the singleton clusters $(<2$ member sequences) were filtered. Operational Taxonomic Unit (OTU) selection was performed using the UPARSE algorithm to classify the large number of clusters into OTUs. Chimera checking was performed on the selected OTUs using the UCHIME (Edgar et al., 2011) chimera detection software executed in de-novo mode. Each clustered centroid was then mapped to their corresponding OTUs and chimeric sequences were then removed. Reads were then mapped to their corresponding non-chimeric cluster and taxonomies were assigned using the RDP classifier algorithm (Cole et al., 2008) against UNITE database to form a OTU table. For each taxonomic level (phylum to species), the sequences and its corresponding percentages per full taxonomic match per sample were calculated, and the diversity indices, 
i.e Shannon-Wiener diversity index $(\mathrm{H})$, species richness (S), evenness (E) were calculated by OTUs using this formula:

$$
\begin{aligned}
& \mathrm{H}=-\mathrm{SUM}\left[(\mathrm{pi}) * \ln (\mathrm{pi})^{-}\right. \\
& \mathrm{E}=\mathrm{H} / \mathrm{H}_{\max }
\end{aligned}
$$

Where, $\mathrm{SUM}=$ Summation, $\mathrm{pi}=$ Number of individuals of species $\mathrm{i} /$ total number of samples $\mathrm{S}=$ Number of species or species richness, Hmax = Maximum diversity possible, $\mathrm{E}=$ Evenness Soil chemical and biological data were subjected to analysis of variance (ANOVA) using the general linear model (GLM) procedure of the SPSS software version 17.0 (SPSS Inc., Chicago, USA). The treatment means were separated by the Duncan Multiple Range Test at 5\% level of significance $(\mathrm{P}<0.05)$. The sequences of this study have been submitted to NCBI under BioProject Accession: PRJNA260467, BioSample: SAMN03023598.

\subsection{Crop yield}

The wheat samples were collected from four locations from each plot in April 2014. Crop was harvested manually from randomly selected $4 \times 5 \mathrm{~m}^{2}$ quadrants for grain yield. Grain yield of crops was recorded at $14 \%$ moisture basis.

\section{Results}

\subsection{Soil chemical and biological properties}

The soil EC was significantly not different among the managements and varied from 0.22 to $0.26 \mathrm{dS} / \mathrm{m}$ (Table 3). Similarly, pH ranged from 7.84 to 7.88 (Table 3), and the lowest $\mathrm{pH}$ (7.60) was recorded in the CTR-ZTWMb management. Organic carbon (OC) was significantly higher in partial CA (CTR-ZTWMb) and full CA (ZT-MWMb and ZT-RWMb) based managements by $30 \%, 43 \%$, and $47 \%$, respectively compared to conventional agriculture (CT-RW) based management (Table 3). Microbial biomass carbon (MBC) was highest $\left(265.92 \mu \mathrm{g} \mathrm{g}^{-1}\right.$ dry soil) in ZT-MWMb followed by ZT-RWMb (231.97 $\mu \mathrm{g} \mathrm{g}^{-1}$ dry soil); In full CA-based managements (ZT-RWMb and ZTMWMb), MBC was increased by $36 \%$ and $56 \%$, and microbial biomass nitrogen (MBN) by $66 \%$ and $70 \%$, respectively compared to conventional agriculture (CT-RW) (Table 3). Higher phosphatase activity (APA) was observed under ZT-MWMb (59.23 $\mu \mathrm{g}$ p-NP g soil $\left.{ }^{-1} \mathrm{~h}^{-1}\right)$ and ZT-RWMb (55.76 $\mu \mathrm{g}$ p-NP g soil ${ }^{-1} \mathrm{~h}^{-1}$ ), being $73 \%$ and $63 \%$ higher than CT-RW, respectively. Dehydrogenase activity (DHA) was significantly higher under ZT-MWMb $(62.88 \mu \mathrm{g}$ TPF g soil $\left.24 \mathrm{~h}^{-1}\right)$ and ZT-RWMb (63.16 $\mu \mathrm{g}$ TPF g soil 24 $\left.\mathrm{h}^{-1}\right)$ compared to CTR-ZTWMb and CT-RW (51.14 $\mu \mathrm{g}$ TPF g soil $24 \mathrm{~h}^{-1}$ and $37.26 \mu \mathrm{g}$ TPF g soil $24 \mathrm{~h}^{-1}$ ) (Table 3). Activity of $\beta$-glucosidase was statistically similar in ZT-MWMb and ZT-RWMb, however it was significantly higher compared to CT-RW (Table 3). ZT-MWMb and ZT-RWMb had $40 \%$ and $41 \%$ higher $\beta$-glucosidase activity compared to CT-RW (Table 3).

\subsection{Fungal community abundance}

From the four managements, a total of 2,32,024 qualityfiltered sequences were obtained from extracted DNA. After the taxonomy based analysis of these sequences, it was found that at the phylum level, soils of all the four managements were dominated by Ascomycota followed by Basidiomycota and Glomeromycota. The relative abundance of Ascomycota was ranged from 55 to $74 \%$, with the highest dominance found in ZT-MWMb (74\%) followed by ZT-RWMb (71\%), CTR-ZTWMb (68\%), and CT-RW (55\%), Basidiomycota and Glomeromycota did not follow any trend as both of these phyla were found in an abundance between 0 to $3 \%$ (Figure 2). In total, 11 well defined classes were observed out of which Sordariomycetes had the highest abundance 
and it was found in all managements, this class was followed in abundance by Dothideomycetes and
Eurotiomycetes (Figure 3a). Some classes were not evenly distributed among managements.

Table 3. Soil chemical biological properties and crop yield

\begin{tabular}{|c|c|c|c|c|c|c|c|c|c|}
\hline Scenarios & $\begin{array}{c}\mathrm{EC} \\
(\mathrm{dS} / \mathrm{m})\end{array}$ & $\mathrm{pH}$ & $\mathrm{OC}$ & $\begin{array}{c}\text { MBC } \\
(\mu \mathrm{g} / \mathrm{g} \text { dry } \\
\text { soil })\end{array}$ & $\begin{array}{c}\text { MBN } \\
\text { ( } \mu \mathrm{g} / \mathrm{g} \text { dry } \\
\text { soil) }\end{array}$ & $\begin{array}{c}\text { APA } \\
(\mu \mathrm{g} \text { p-NP/ } \\
\text { g soil } / \mathrm{h})\end{array}$ & $\begin{array}{c}\text { DHA } \\
(\mu \mathrm{g} \text { TPF /g } \\
\text { soil/ } 24 \mathrm{~h})\end{array}$ & $\begin{array}{c}\beta- \\
\text { Glucosidase } \\
(\mu \mathrm{g} \mathrm{p}-\mathrm{NP} / \mathrm{g} \\
\text { soil } / \mathrm{h})\end{array}$ & $\begin{array}{c}\text { Wheat } \\
\text { yield } \\
\left(\mathrm{Mg} \mathrm{ha}^{-1}\right)\end{array}$ \\
\hline CT-RW & $0.26 \pm 0.03^{\mathrm{a}}$ & $7.88 \pm 0.08^{\mathrm{a}}$ & $0.47 \pm 0.03^{\mathrm{b}}$ & $170.0 \pm 8.66^{\mathrm{c}}$ & $58.8 \pm 4.36^{\mathrm{c}}$ & $34.18 \pm 4.71^{\mathrm{c}}$ & $37.26 \pm 4.56^{\mathrm{b}}$ & $36.23 \pm 2.49^{b}$ & $5.01 \pm 0.36^{\mathrm{a}}$ \\
\hline CTR-ZTWMb & $0.23 \pm 0.04^{\mathrm{a}}$ & $7.60 \pm 0.11^{\mathrm{b}}$ & $0.61 \pm 0.04^{\mathrm{a}}$ & $207.0 \pm 12.74^{b}$ & $79.9 \pm 4.81^{b}$ & $52.34 \pm 5.37^{\mathrm{a}}$ & $51.14 \pm 4.82^{\mathrm{ab}}$ & $43.12 \pm 1.79^{\mathrm{ab}}$ & $5.38 \pm 0.20^{\mathrm{a}}$ \\
\hline ZT-RWMb & $0.23 \pm 0.03^{a}$ & $7.87 \pm 0.13^{\mathrm{a}}$ & $0.69 \pm 0.05^{\mathrm{a}}$ & $232.0 \pm 10.99^{b}$ & $97.7 \pm 4.30^{\mathrm{a}}$ & $55.76 \pm 4.16^{\mathrm{a}}$ & $63.16 \pm 7.09^{\mathrm{a}}$ & $51.24 \pm 1.92^{\mathrm{a}}$ & $5.38 \pm 0.20^{\mathrm{a}}$ \\
\hline ZT-MWMb & $0.22 \pm 0.05^{\mathrm{a}}$ & $7.84 \pm 0.10^{\mathrm{a}}$ & $0.67 \pm 0.02^{\mathrm{a}}$ & $265.9 \pm 13.81^{\mathrm{a}}$ & $99.7 \pm 5.10^{\mathrm{a}}$ & $59.23 \pm 4.05^{\mathrm{a}}$ & $62.88 \pm 4.84^{\mathrm{a}}$ & $50.83 \pm 2.68^{\mathrm{a}}$ & $5.41 \pm 0.31^{\mathrm{a}}$ \\
\hline
\end{tabular}

For all variables $n=3 \pm$ standard error of mean. Different small letters within the same column show the significant difference at $\mathrm{P}=0.05$ according to Duncan Multiple Range Test for separation of mean

$C T-R W$ conventional tillage rice-wheat, $C T R-Z T W M b$ conventional tillage rice- zero tillage wheat and mungbean, ZT-RWMb zero tillage ricewheat-mungbean, $Z T-M W M b$ zero tillage maize-wheat-mungbean, $E C$ electric conductivity, $O C$ organic carbon, $M B C$ microbial biomass carbon, $M B N$ microbial biomass nitrogen, $A P A$ Phosphatase activity, DHA Dehydrogenase activity

The presence of Leotiomycetes was recorded only in ZT-RWMb and ZT-MWMb, whereas Pezizomycetes was found only in CTR-ZTWMb. Agaricomycetes was found only in CT-RW and CTR-ZTWMb. Three OTUs of Wallemiomycetes were found exclusively in ZT-MWMb. The dominating orders in all four managements were: Sordariales, Hypocreales and Pleosporales of the Ascomycota phylum (Figure $3 \mathrm{~b})$. The pattern of abundance of these three orders was similar in all four managements as Sordariales was dominating (17-40\%), followed by Hypocreales, and Pleosporales. In CT-RW (Figure 4a), Alternaria was the most abundant genus (13.52\%), followed by Stachybotrys (10\%), whereas in CTR-ZTWMb (Figure $4 \mathrm{~b})$ Podospora (15.08\%) was the most abundant genus, followed by Alternaria (10.08\%). In ZT-RWMb (Figure 4c), Epicoccum (19.67\%) was the most abundant genus, followed by Cercophora (7.98\%), and in ZT-MWMb (Figure 4d), an unclassified genus of the
Sordariaceae family $(10.50 \%)$ was the most abundant, followed by an unclassified genus of the Nectriaceae family (10.12\%). Different diversity indices were calculated: the maximum number of fungal species was found in ZT-MWMb (95), followed by CTR-ZTWMb (91), ZT-RWMb (85), and CT-RW (54) (Table 4). The same trend was observed for the Shannon-Wiener diversity index, as it was higher in ZT-MWMb, CTRZTWMb and ZT-RWMb by $10 \%, 9 \%$, and $35 \%$, respectively, when compared to CT-RW (Table 4).

\subsection{Crop yield}

The wheat yield was recorded higher in ZT-MWMb $\left(5.41 \mathrm{Mg} \mathrm{ha}^{-1}\right)$ but significantly at par with other management practices (Table 3 ). The wheat grain yields were recorded higher by $8 \%, 7 \%$ and $5 \%$ for ZTRWMb and CTR-ZTWMb, respectively, when compared to CT-RW (5.01 $\left.\mathrm{Mg} \mathrm{h}^{-1}\right)$ 


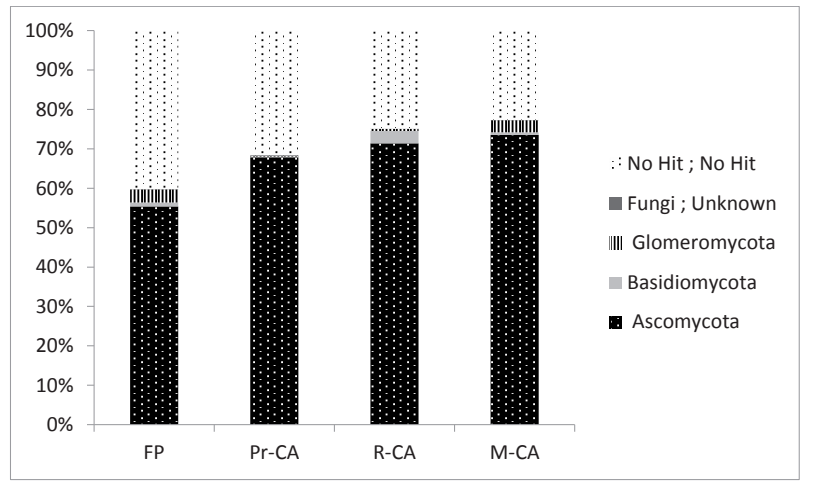

Figure 2. Distribution of different Phyla in the four managements

$C T-R W$ : conventional tillage rice-wheat; $C T R-Z T W M b$ : conventional tillage rice- zero tillage wheat and mungbean; $Z T-R W M b$ : zero tillage rice-wheat-mungbean; $Z T-M W M b$ : zero tillage maize-wheat-mungbean

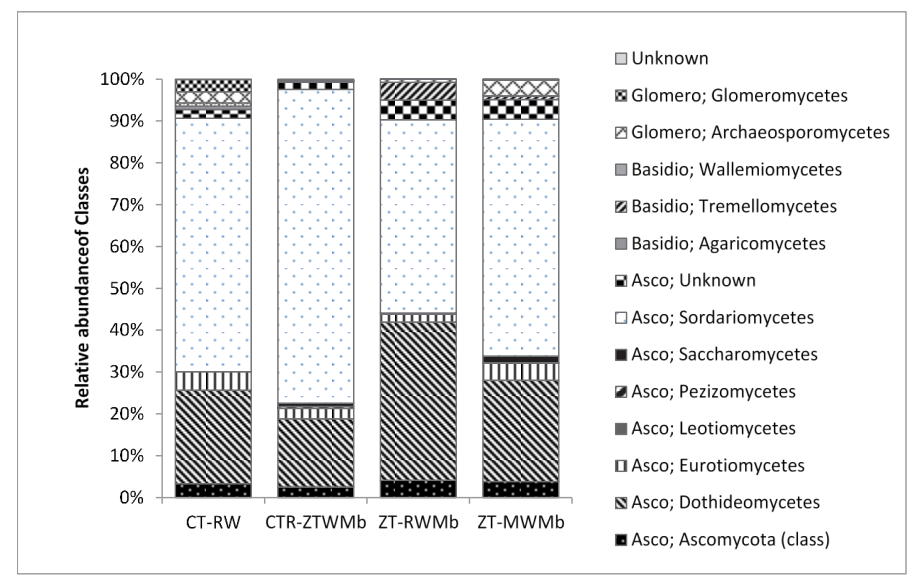

(a)

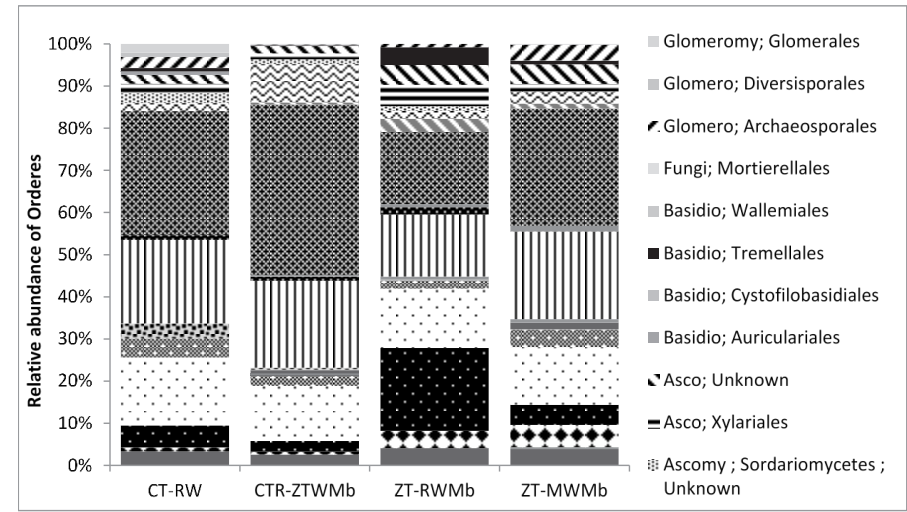

Figure 3. Relative abundance of (a) Classes and (b) Orders in four different managements

CT-RW: conventional tillage rice-wheat; CTR -ZTWMb: conventional tillage rice- zero tillage wheat and mungbean; ZT-RWMb: zero tillage rice-wheat-mungbean; ZT-MWMb: zero tillage maize-wheat-mungbean 

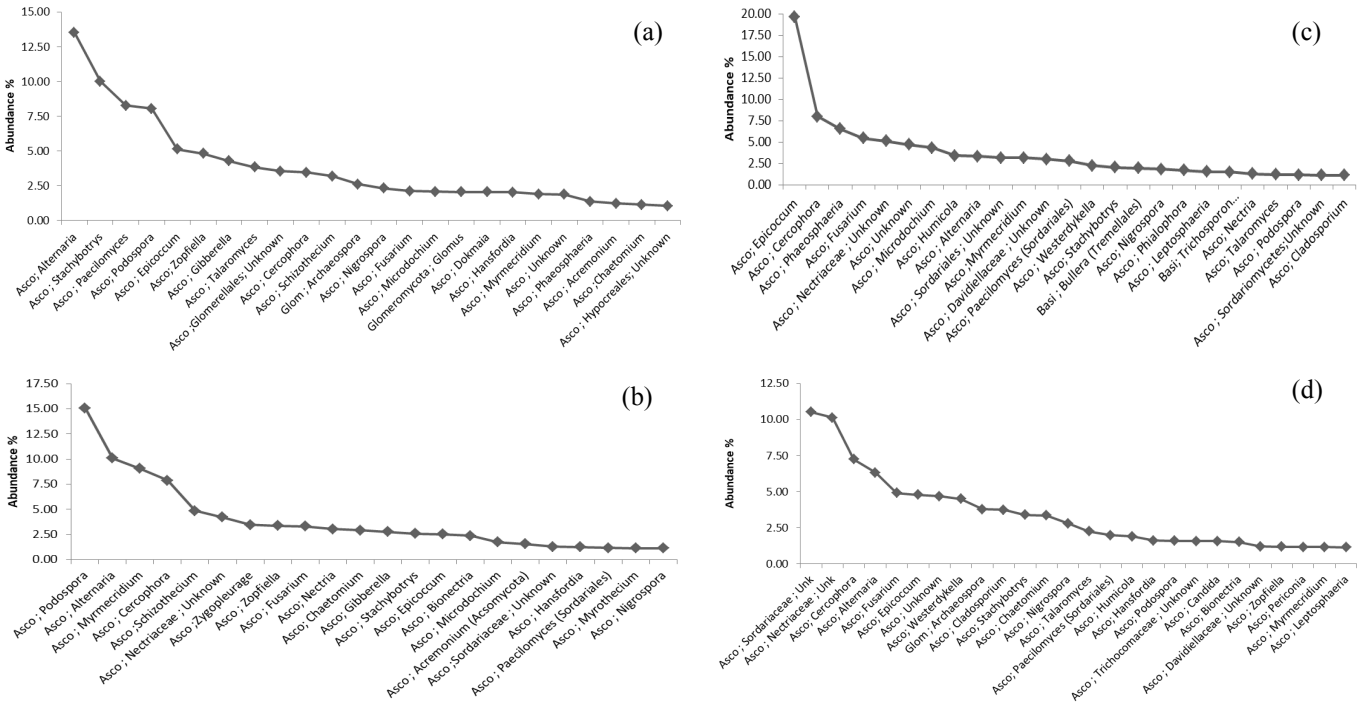

Figure 4. Distribution of different genera in $C T-R W(\mathrm{a}), C T R-Z T W M b(\mathrm{~b}), Z T-R W M b(\mathrm{c})$, and $Z T-M W M b(\mathrm{~d})$

Table 4. Diversity indices of fungi in scenarios

\begin{tabular}{|c|c|c|c|c|}
\hline Diversity indices & $\begin{array}{l}\text { CT- } \\
\text { RW }\end{array}$ & $\begin{array}{l}\text { CTR- } \\
\text { ZTWMb }\end{array}$ & $\begin{array}{l}\text { ZT- } \\
\text { RWMb }\end{array}$ & $\begin{array}{l}\text { ZT- } \\
\text { MWMb }\end{array}$ \\
\hline Species richness $\mathrm{S}$ & 54 & 91 & 85 & 95 \\
\hline $\begin{array}{l}\text { Shannon-Wiener } \\
\text { Index }(\mathrm{H})\end{array}$ & 3.22 & 3.49 & 3.34 & 3.54 \\
\hline Evenness $(E)=H / H \max$ & 0.807 & 0.773 & 0.751 & 0.777 \\
\hline
\end{tabular}

$C T-R W$ conventional tillage rice-wheat, $C T R-Z T W M b$ conventional tillage rice- zero tillage wheat and mungbean, $Z T-R W M b$ zero tillage rice-wheat-mungbean, $Z T-M W M b$ zero tillage maize-wheat-mungbean 


\section{Discussion}

\subsection{Chemical and biological soil properties}

Conservation agriculture management practices where zero-tillage coupled with residue retention revealed higher OC content in soils compared to conventional agriculture (Jat et al., 2017). As crop residues decompose slowly under zero-tillage, and, organic matter thus gradually accumulates in the soil, which might have caused higher OC contents under CA-based managements (Dikgwatlhe et al., 2014). Soil organic matter serves as a good source of energy for soil microbes, positively affecting microbial growth and hence influences their distribution (Wang et al., 2016). Conservation agriculture based practices increases soil microbial biomass and activity viz., MBC, MBN, phosphatase, DHA, and $\beta$-glucosidase in full CA-based managements (ZT-RWMb and ZT$\mathrm{MWMb}$ ), because of a minimum disturbance of the soil system. Conservation agriculture system favored increased levels of microbial biomass carbon/ nitrogen, when compared to conventional agriculture; this might be due to increased associated $\mathrm{C}$ inputs, residue retention, and reduced tillage (Wang et al., 2012). Cropping systems also affected MBC and MBN as these were found in higher amounts in multi cropping systems, when compared to one or two crop rotations (Moore et al., 2000). Diverse type of crops secretes diverse root exudates, and also provide diverse types of crop residues in the soil, which affects microbial diversity, density, and growth (Venter et al., 2016).

\subsection{Enzyme activities}

Conservation agriculture based managements reflected the higher soil enzymes activities (Table 3), compared to CT management. In CA, residue recycling, zero tillage, and crop rotation play a significant role in increasing higher soil enzyme activities . High concentration of residues along with roots of previous crops in the surface soil, affects its microbial activity to a wider extent under undisturbed soil. The beneficial effect of crop roots, i.e. "the rhizosphere effect", probably contributes significantly towards higher enzyme activities under CA management compared to CT systems (Bandick and Dick, 1999). In CT systems, soil moisture holding capacity is comparatively lower than CA systems because of crop residues retention and this influences moisture availability period which ultimately influences the enzyme activities under CT systems (Jin et al., 2009). The phosphatase activities are highly influenced by agricultural practices, tillage, cropping systems, and crop residues managements. No-till with residue retention on the soil surface increases the total soil $\mathrm{P}$ and phosphatases activity (Wang et al., 2011), as it increases the supply of readily available substrates, such as carbohydrates for microorganisms. Dehydrogenase activity (DHA) is highly influenced by tillage operations as it decreases with intensive tillage (Rolden et al., 2005). $\beta$-glucosidase was found higher with CA based cereal (R/W) systems compared to conventional farmers practice (CT-RW). $\beta$-glucosidase plays an important role in the $\mathrm{C}$ cycle, as it involves in the microbial degradation of cellulose to glucose (Eivazi and Tabatabai, 1990).

\subsection{Fungal diversity}

Apart from SOC and enzyme activities, agriculture management practices also influences microbial diversity (Govaerts et al., 2007). Higher microbial diversity was observed under full CA-based management practices due to the continuous presence of the crop residues on soil surface throughout the year. Reduced disturbances in ZT systems may favor fungal growth and activity due to enhanced establishment and maintenance of extensive hyphal networks. 
Bailey et al. (2002) reported a shift towards fungal dominated microbial communities under zero-tillage, which are important for residue decomposition and nutrient cycling processes, and bear the closest resemblance to natural ecosystems. In our study, Ascomycota was the dominating phylum, followed by Basidiomycota in all the four managements. A similar dominance of Ascomycota, followed by Basidiomycota, was also reported by Miura et al., 2015 with no-tillage. The maximum crop residue biomass in ZTMWMb might be responsible for the highest (74\%) abundance of Ascomycota (Figure S1) as these fungi are mainly responsible for residue degradation. Moreover, an intrinsic quality of the substrate may also influence abundance of Ascomycota, as in ZT-MWMb the quality of retained crop residues is different than other three managements. In ZT-MWMb residue of maize was retained but in rest three managements rice residue was retained. Classes of Ascomycota viz., Sordariomycetes, Dothideomycetes, and Eurotiomycetes were the dominating classes in all four managements which is in accordance with a previous study (Wang et al., 2016). Members of Sordariomycetes are found in residue-rich soils, as these fungi have the potential to produce cellulolytic enzymes (Phosri et al., 2012). The Dothideomycetes also represents a dominant class in the phylum Ascomycota, which are found as endophytes or epiphytes on living plants, and act as saprobes degrading cellulose and other complex carbohydrates in dead or partially digested plant organic matter (Hyde et al., 2013). In our study, Sordariales followed by Hypocreales were the dominating Ascomycetous orders; similar observations were also reported by Klaubauf et al., (2010), with both molecular and traditional cultivation approaches in agricultural soils. : In this study it was found that dominating phyla, classes and orders were similar in all managements but distribution of genera varied. It may be because of different practices (tillage, crop establishment and residue recycling) under these managements did not much influence Ascomycota at higher level of classification (phylum, class and order) but affects at genera level (Wang et al., 2016). Unclassified genera of Sordariaceae and Nectriaceae were dominant only under maize based systems, however other unclassified genera were dominant in rice based managements. This might be due to difference in accessible $\mathrm{C}$ sources and $\mathrm{N}$ availability in the diverse (maize and rice) crop residues (Miura et al., 2015 ) in different managements. Several genera constituting less than $1 \%$ of abundance are not shown in figures (Figure4 a-d) but these taxa may contribute to the compositional uniqueness of the soil.

\subsection{Diversity indices}

When comparing diversity indices, ZT-MWMb showed higher diversity compared to other managements which indicates more stability of that management system (Giller et al., 1997). Tillage plays a major role in influencing the microbial densities under agricultural soils (Wang et al., 2016). Similarly observations of higher levels of bacterial diversity with no-till compared to conventional-till system was reported by Ceja-Navarro et al., (2010). Under CAbased management systems, not only zero tillage but crop residues also play major roles in determining fungal dominance, as residues serve a continuous energy source for microorganisms, and retention of these crop residues on the soil surface increases their abundance by providing improved conditions for reproduction (Salinas-Garcia et al., 2002). The highest species richness in ZT-MWMb can be correlated with the presence of maize in crop rotation system which provide greater amounts of plant residue with more decomposability that would support greater microbial populations and diversity compared to rice residues (Moore et al., 2000). 


\subsection{Crop yield}

Result of our study clearly showed the effect of ZT, crop establishment and residue retention/incorporation on wheat crops yields. Higher yields of wheat with CA-based management practices might be due to the compound effects of many factors like better soil quality (Choudhary et al., 2018), improved soil physical and chemical properties (Jat et al., 2017), and improved micro-climatic conditions that results in a lesser terminal heat effect (Gathala et al., 2013).

\section{Conclusions}

This study showed that soil organic carbon and biological properties are influenced by CA based management practices. Organic carbon, $\mathrm{MBC}, \mathrm{MBN}$, APA, DHA and $\beta$-glucosidase were found higher under CA-based systems, compared to the conventional system (CT-RW), all of which resulted in highr wheat yields. The soil fungal communities at the phylum, class, and order levels varied among managements. All the four managements were dominated by Ascomycota, followed by Basidiomycota and Glomeromycota, but the abundance of these phyla varied with management systems. Thwe CA based maize-wheatmungbean system (ZT-MWMb) showed more fungal diversity than the rice based systems (CT-RW, CTRZTWMb and ZT-RWMb). Zero tillage with residue retention under efficient crop sequence increases the soil microbial properties, and thus increases soil fungal diversity and richness.

\section{Acknowledgements}

We acknowledge that this research was undertaken in collaboration with the International Maize and Wheat Improvement Centre (CIMMYT), under the Cereal Systems Initiative for South Asia (CSISA), a project supported by the Bill and Melinda Gates Foundation (BMGF), USAID, and the CGIAR Research Programs on Climate Change, Agriculture and Food Security (CCAFS) and Wheat Agri-food Systems (WHEAT). We also acknowledge the support received from the Director of ICAR-CSSRI, Karnal.

\section{References}

Alef, K. , Nannipieri, P. 1995. $\beta$-Glucosidase activity. Methods in applied soil microbiology and biochemistry, pp.350-352. Andrews, S. 2010. Fast QC: a quality control tool for high throughput sequence data. pp. 175-176.

Bailey, V.L., Smith, J.L. Bolton, H. 2002. Fungal-tobacterial ratios in soils investigated for enhanced C sequestration. Soil Biol. Biochem. 34, 9971007.

Bandick, A.K., Dick, R.P. 1999. Field management effects on soil enzyme activities. Soil Biol. Biochem. 31, 1471-1479.

Ceja-Navarro, J.A., Rivera-Orduna, F.N., PatinoZúniga, L., Vila-Sanjurjo, A., Crossa, J., Govaerts, B., Dendooven, L. 2010. Phylogenetic and multivariate analyses to determine the effects of different tillage and residue management practices on soil bacterial communities. Appl. Environ. Microbiol. 76, 3685-3691.

Choudhary, M., Sharma, P.C., Jat, H.S., Nehra, V., McDonald, A.J., Garg, N. 2016. Crop residue degradation by fungi isolated from conservation agriculture fields under rice-wheat system of North-West India. Int. J. Recycl. Org. Waste Agricult. 5, 349-360.

Choudhary M, Jat HS, Datta A, Yadav AK, Sapkota TB, Mondal S, Meena RP, Sharma PC, Jat ML (2018). Sustainable intensification influences soil quality, biota, and productivity in cereal-based agroecosystems. Appl Soil Eco 126: 189-198 
Cole, J.R., Wang, Q., Cardenas, E., Fish, J., Chai, B., Farris, R.J., Kulam-Syed-Mohideen, A.S., McGarrell, D.M., Marsh, T., Garrity, G.M., Tiedje, J.M. 2008. The Ribosomal Database Project: improved alignments and new tools for rRNA analysis. Nucleic acids research, 37(suppl_1), D141-D145.

Dick, R.P. 1997. Soil enzyme activities as integrative indicators of soil health. In 'Biological indicators of soil health' (Eds Pankhurst CE, Doube BM, Gupta VVSR) pp. 121-156. (Wallingford (UK): $\mathrm{CAB}$ International)

Dikgwatlhe, S.B., Chen, Z.D., Lal, R., Zhang, H.L., Chen, F. 2014. Changes in soil organic carbon and nitrogen as affected by tillage and residue management under wheat-maize cropping system in the North China Plain. Soil Till. Res. 144, 110118.

Edgar, R.C. 2010. Usearch. Lawrence Berkeley National Laboratory (LBNL), Berkeley, CA (United States). Edgar, R.C., Haas, B.J., Clemente, J.C., Quince, C., Knight, R. 2011. UCHIME improves sensitivity and speed of chimera detection. Bioinformatics 27, 2194-2200.

Eivazi, F., Tabatabai, M.A. 1977. Phosphatases in soils. Soil Biol. Biochem. 9, 167-172. Eivazi, F., Tabatabai, M.A. 1990. Factors affecting glucosidase and galactosidase activities in soils. Soil Biol. Biochem. 22, 891-897.

Gathala, M., Kumar, V., Sharma, P.C., Saharawat, Y., Jat, H.S., Singh, M., Kumar, A., Jat, M., Humphreys, E., Sharma, D.K., Sharma, S., Ladha, J.K. 2013. Optimizing intensive cereal-based cropping systems addressing current and future drivers of agricultural change in the northwestern IndoGangetic Plains of India. Agr. Ecosyst. Environ. 177, 85-97.

Giller, K.E., Beare, M.H., Lavelle, P., Izac, A.M., Swift, M.J. 1997. Agricultural intensification, soil biodiversity and agroecosystem function. Appl Soil Ecol. 6, 3-16.

Govaerts, B., Mezzalama, M., Unno, Y., Sayre, K.D., Luna-Guido, M., Vanherck, K., Dendooven, L., Deckers, J. 2007. Influence of tillage, residue management, and crop rotation on soil microbial biomass and catabolic diversity. Appl. Soil. Ecol. $37,18-30$.

Hyde, K.D., Jones, E.G., Liu, J.K., Ariyawansa, H., Boehm, E., Boonmee, S., Braun, U., Chomnunti, P., Crous, P.W., Dai, D.Q., Diederich, P. 2013. Families of Dothideomycetes. Fungal Divers. 63, 1-313.

Jackson, M.L. 1973. Soil chemical analysis. Prentice Hall of India Pvt Ltd, New Delhi. 42. Jat, H.S., Datta, A., Sharma, P.C., Kumar, V., Yadav, A.K., Choudhary, M., Choudhary, V., Gathala, M.K., Sharma, D.K., Jat, M.L., Yaduvanshi, N.P.S., 2017. Assessing soil properties and nutrient availability under conservation agriculture practices in a reclaimed sodic soil in cereal-based systems of North-West India. Arch. Agron. Soil Sci., pp.1-15.

Jin, K., Sleutel, S., Buchan, D., De Neve, S., Cai, D.X., Gabriels, D., Jin, J.Y. 2009. Changes of soil enzyme activities under different tillage practices in the Chinese Loess Plateau. Soil Till. Res. 104, 115-120.

Klaubauf, S., Inselsbacher, E., Zechmeister-Boltenstern, S., Wanek, W., Gottsberger, R., Strauss, J., Gorfer, M. 2010. Molecular diversity of fungal communities in agricultural soils from Lower Austria. Fungal divers. 44, 65-75.

Lohan, S.K., Jat, H.S., Yadav, A.K., Sidhu, H.S., Jat, M.L., Choudhary, M., Peter, J.K., Sharma, P.C. 2018. Burning issues of paddy residue management in north-west states of India. Renew Sust Energ Rev 81, 693-706.

Madejón, E., Murillo, J.M., Moreno, F., Lüpez, M.V., Arrue, J.L., Alvaro-Fuentes, J., Cantero, C. 2009. 
Effect of long term conservation tillage on soil biochemical properties in Mediterranean Spanish areas. Soil Till. Res. 105, 55-62.

Marín, C., Godoy, R., Valenzuela, E., Schloter, M., Wubet, T., Boy, J., Gschwendtner, S., 2017. Functional land-use change effects on soil fungal communities in Chilean temperate rainforests. J. Soil Sci. Plant Nutr. 17, 985-1002.

Miura, T., Niswati, A., Swibawa, I.G., Haryani, S., Gunito, H., Shimano, S., Fujie, K., Kaneko, N. 2015. Diversity of fungi on decomposing leaf litter in a sugarcane plantation and their response to tillage practice and bagasse mulching: implications for management effects on litter decomposition. Microbial. Ecol. 70, 646-658.

Moore, J.M., Klose, S., Tabatabai, M.A. 2000. Soil microbial biomass carbon and nitrogen as affected by cropping systems. Biol. Fert. Soils. 31, 200210.

Phosri, C., Polme, S., Taylor, A.F., Koljalg, U., Suwannasai, N., Tedersoo, L. 2012. Diversity and community composition of ectomycorrhizal fungi in a dry deciduous dipterocarp forest in Thailand. Biodivers. Conserv. 21, 2287-2298.

Rolden, A., Salinas-García, J.R., Alguacil, M.M., Díaz, E., Caravaca, F. 2005. Soil enzyme activities suggest advantages of conservation tillage practices in sorghum cultivation under subtropical conditions. Geoderma. 129, 178-185.

R., de J Velázquez-García, J., Gallardo-Valdez, M., Diaz-Mederos, P., Caballero-Hernández, F., Tapia-Vargas, L.M., Rosales-Robles, E. 2002. Tillage effects on microbial biomass and nutrient distribution in soils under rain-fed corn production in central-western Mexico. Soil Till Res. 66, 143-152.
Sarkar, S. 2015. Management practices for enhancing fertilizer use efficiency under rice-wheat cropping system in the Indo-Gangetic plains. Innovare J Agric Sci, 3,5-10.

Vance, E.D., Brookes, P.C., and Jenkinson, D.S. 1987. An extraction method for measuring soil microbial biomass C. Soil Biol. Biochem. 19, 703-707.

Venter, Z.S., Jacobs, K., and Hawkins, H.J. 2016. The impact of crop rotation on soil microbial diversity: A meta-analysis. Pedobiologia 59, 215-223.

Wang, J.B., Chen, Z.H., Chen, L.J., Zhu, A.N., Wu, Z.J. 2011. Surface soil phosphorus and phosphatase activities affected by tillage and crop residue input amounts. Plant Soil and Environ. 57, 251257.

Wang, J.J., Li, X.Y., Zhu, A.N., Zhang, X.K., Zhang, H.W., Liang, W.J. 2012. Effects of tillage and residue management on soil microbial communities in North China. Plant Soil Environ. 58, 28-33.

Wang, Z., Chen, Q., Liu, L., Wen, X., Liao, Y. 2016. Responses of soil fungi to 5-year conservation tillage treatments in the drylands of northern China. Appl. Soil Ecol. 101, 132-140.

Zhang, J., Kobert, K., Flouri, T., Stamatakis, A., 2013. PEAR: a fast and accurate Illumina Paired-End read merger. Bioinformatics, 30(5), 614-620. 